\title{
Distribution and growth in adults of Macrobrachium acanthurus Wiegmann, (Decapoda, Palaemonidae) in a tropical coastal lagoon, Brazil
}

\author{
Edélti Faria Albertoni ${ }^{1,3}$ \\ Cleber Palma-Silva ${ }^{1}$ \\ Francisco de Assis Esteves ${ }^{2}$
}

\begin{abstract}
Macrobrachium acanthurus Wiegmann, 1836 is a Palaemonidae commonly found in Brazilian coastal environments. At Imboassica lagoon, located in the north of the State of Rio de Janeiro, it is found in two stages of its life cycle: as larvae and as reproductive adults. This work had as its goal the evaluation of adults distribution, estimating the weight/length relationship and the condition factor of these adults. After sampling in two regions of the lagoon, one interior and another closer to the ocean, we verified that females are found in a greater proportion close to the ocean, and males are found in greater number in the innermost region, amidst the aquatic macrophytes, suggesting that the fecundation takes place in this last area and the females then travel to the area closer to the ocean to spawn. Total and carapace weight/length relationship exhibited differences between males and females, presenting positive allometric growth. The relative growth of the cephalotorax related to total length showed that it correspond to $53 \%$ of the total length in females, and $50 \%$ in males. The average condition factor was significantly lower than the expected pattern, demonstrating that the species does not find ideal conditions in the lagoon. This may be attributed to the migration of the adults, to the spawning and/or to the impact caused by the frequent sandbar openings that took place at Imboassica lagoon during the studied period.

KEY WORDS. Palaemonidae, Macrobrachium acanthurus, coastal lagoon, weight/length relationship, condition factor
\end{abstract}

The genus Macrobrachium Bate, 1868 encompasses species that thrive in lotic and lentic environments, being found in several aquatic systems in Brazil, both in freshwater and in mesohaline environments (COELHO \& RAMOS-PORTO 1985; VALENTI 1985). Studies focusing on different ecological and biological aspects of several species have been executed in some areas in Brazil, and among them we may underline the works of BOND \& BUCKUP (1982), LOBÃO et al. (1986a, b), VALENTI et al. (1989), BOND-BUCKUP \& BUCKUP (1989), MÜLler \& PRAZERES (1992) and MOREIRA \& ODINETZ-COLLART (1993).

1) Laboratório de Ecologia, Departamento de Ciências Morfo-Biológicas, Fundação Universidade Federal do Rio Grande. Avenida Itália Km 8, 96201-900 Rio Grande, Rio Grande do Sul, Brasil.

2) Departamento de Ecologia, Instituto de Biologia, Universidade Federal do Rio de Janeiro. Caixa Postal 68020, 21941-540 Rio de Janeiro, Rio de Janeiro, Brasil.

3) Corresponding author. 
Macrobrachium acanthurus is found from North Carolina (USA) to Rio Grande do Sul State (Brazil) (BOND-BUCKUP \& BUCKUP 1989; CAMACHO et al. 1997), being a relatively common species in Brazilian estuaries, reservoirs and rivers that are linked to the sea (HOLTHUIS 1980; VALENTI et al. 1987). Its larvae need brackish waters for their development (DOBKIN 1970), and it is for this reason classified as a coastal continental species by COELHO \& RAMOS-PORTO (1985). The information about the species in the coast of Rio de Janeiro is composed by a few observations by OLIVEIRA (1948) and OLIVEIRA \& KRAU (1955), and in recent years by AlBerTONi (1998a, b) and ALBERTONI et al. (1999, 2001).

The main goal of this work was to evaluate the adult distribution of $M$. acanthurus at Imboassica lagoon, and establish the species general conditions in this environment, through the determination of the weight/length relationship and of the condition factor for it.

\section{MATERIAL AND METHODS}

Imboassica lagoon is a coastal lagoon, located in the urban area of Macaé ( $22^{\circ} 50^{\prime} \mathrm{S} ; 44^{\circ} 42^{\prime} \mathrm{W}$, Rio de Janeiro State). Its present area is $3.26 \mathrm{Km}^{2}$, and a medium depth of $1.1 \mathrm{~m}$ (PANOSSO et al. 1998), with a extension of $2 \mathrm{~km}$ and width of about $800 \mathrm{~m}$. This water body was formed by the damming up of the Imboassica river and is today isolated from the sea by a sandbar with approximately 50 meters of length. This lagoon has been exposed to several human impacts, as the dumping of domestic sewage and artificial breachings of the sandbar. These breachings have drastic consequences for the ecosystems, since the water level drops considerably and the metabolism of the lagoon is altered (FARIA et al. 1998).

After the sandbar is closed, the lagoon is filled by a mixture of sea water that remained in it, freshwater from the Imboassica river, and rain water (PETRUCIO 1998). Therefore, the lagoon remains mesohaline in the first months after the sandbar breaching, and gradually becomes oligohaline (BRANCO 1998), a condition that may enhance the egg production and larvae growth for Macrobrachium acanthurus.

The samplings of Macrobrachium acanthurus took place at Imboassica lagoon, in two areas: one close to the sandbar (Station 1) and the other in the innermost portion of the lagoon (Station 2), in the midst of the emergent and submersed vegetation. Dragnets, throwing nets and traps were used, from December/95 to July/97. The identification of the species followed BOND-BUCKUP \& BUCKUP (1989).

As a trap for the capture in the midst of the stands of aquatic macrophytes, 10 cages were used, and chicken or cow liver was used as bait. The traps were setup in the end of the afternoon and after 10 hours, were examined and the captured animals were withdrawn. This procedure was followed for three nights in each sampling date. After the sampling, the organisms were immediately frozen in ice and taken to the laboratory, for the measurement of total length $\left(\mathrm{L}_{t}\right)$, from the tip of the rostrum to the end of the telson, and the length of the cephalotorax, $\left(\mathrm{L}_{\mathrm{c}}\right)$, from the orbital cavity to the end of the cephalotorax (pachymeter, $0.02 \mathrm{~mm}$ ). Total weight $\left(\mathrm{W}_{\mathrm{t}}\right.$ ) (digital scale, $0.01 \mathrm{~g}$ ) was obtained after they were dried in absorbing paper, extracting the excess of water. 
The weight/total length and weight/ cephalotorax length relationships for males and females was determined according to the equations $\mathrm{W}_{\mathrm{t}}=\mathrm{aL}_{\mathrm{t}}{ }^{\mathrm{b}}$, and $\mathrm{W}_{\mathrm{t}}=$ $\mathrm{aL}_{\mathrm{c}}^{\mathrm{b}}$ where $\mathrm{W}_{\mathrm{t}}=$ total weight; $\mathrm{L}_{\mathrm{t}}=$ total length; $\mathrm{L}_{\mathrm{c}}=$ cephalotorax length; $\mathrm{a}$ and $\mathrm{b}$ = constants (BATSCHELET 1978; WEATHERLEY 1972; WEATHERLEY \& GILL 1987). The relative growth of the cephalotorax in relation to the total length of the organism was determined by the linear relationships with adjustments by the origin between the cephalotorax growth and the total length, through the equation $\mathrm{L}_{\mathrm{c}}=\mathrm{a} \mathrm{L}_{\mathrm{t}}$, where $\mathrm{L}_{\mathrm{c}}=$ cephalotorax length; $\mathrm{L}_{\mathrm{t}}=$ total length, and $\mathrm{a}=$ angle of the relationship (HARTNOLL 1978; LOBÃO \& LONA 1979).

Throughout the sampling period, 4 sandbar breachings took place (November/95; April/96; November/96 and January/97). At each breaching, the adult population of Macrobrachium acanthurus at Imboassica lagoon is intensively fished, or dragged to the sea by the water currents. Therefore, for the comparison of the potential length/weight relationships obtained in each interval between breachings, these relationships were linearized, by logarithmical transformation, and compared by a covariance analysis (ANCOVA, SOKAL \& ROHLF 1979). The same analysis was used in the comparison of the male and female curves.

The Relative Condition Factor $\left(\mathrm{K}_{\mathrm{r}}\right)$ was determined according to LE CREN (1951), following the equation $\mathrm{K}_{\mathrm{r}}=\mathrm{W}_{\mathrm{obs}} / \mathrm{W}_{\exp }$, where $\mathrm{W}_{\exp }=$ expected weight, established through the potential relationship between weight and total length that was previously obtained, and $\mathrm{W}_{\mathrm{obs}}$ is the observed weight, obtained by the individual weighing of the collected organisms.

The obtained $\mathrm{K}_{\mathrm{r}}$ for each animal were divided in two groups, male and female, and statistically compared through the Mann-Whitney non parametric test. The comparative analysis of the average relative condition factor, obtained for males and females, was performed by a Student " $t$ " test, which evaluated the difference between the expected average, or standard, $\mathrm{K}_{\mathrm{r}}(=1)$, and the averages obtained for each group.

The abiotic variables measured were temperature, with a digital thermistor, salinity, with a refractometer, and depth of the water column, with a ruler.

\section{RESULTS}

The total of 355 organisms of $M$. acanthurus were biometrically analyzed, 231 females and 124 males. Females had a range of variation in their total length from $62.8 \mathrm{~mm}$ to $119.1 \mathrm{~mm}$, with higher frequencies in the size classes between 90 and $105 \mathrm{~mm}$, and a mean size of $92.9 \mathrm{~mm}(\mathrm{sd}=10.3)$. The range of variation of the males was from 86.1 to $158.9 \mathrm{~mm}$, with higher frequencies in the size classes between 110 and $140 \mathrm{~mm}$ and a mean size of $122.2 \mathrm{~mm}(\mathrm{sd}=14.1)$.

A marked variation was observed in the values of salinity and depth, especially due to the sandbar breaching events, and the area closest to the sandbar (Station 1) had the highest salinity values. The dates in which the traps were set up, in each sampling month, and the abiotic variables are presented in table I.

The distribution of the species in the lagoon showed a difference in the males and females proportions between the two stations (Mann-Whitney, $\mathrm{p}<0.001$ ). In the area further away from the ocean (Station 2), there was a greater occurrence of 
males, at the proportion of 0.7 females for each male, with 677 specimens being sampled, 389 males and 288 females. In the area closest to the ocean (Station 1), the females are found in greater number, around four females for each male, with 464 organisms being sampled, 373 females and 91 males.

Table I. Sampling dates, deepth of water column (cm), salinity (ppt) and water temperature (ํ) (St1/St2), (N) no traps.

\begin{tabular}{|c|c|c|c|c|}
\hline Month & Traps Date & Deepth $(\mathrm{cm})$ & Salinity (ppt) & Temperature $\left({ }^{\circ} \mathrm{C}\right)$ \\
\hline \multicolumn{5}{|c|}{ Sandbar opening Nov, 02, 1995} \\
\hline Dec/1995 & $\mathrm{N}$ & $37 / 30$ & $15 / 14$ & $28 / 26$ \\
\hline $\operatorname{Jan} / 1996$ & 20 a 24 & $60 / 60$ & $7 / 5$ & $29 / 29$ \\
\hline Feb/1996 & 26 a 30 & $90 / 80$ & $1 / 1$ & $29 / 31$ \\
\hline Mar/1996 & 22 a 25 & $90 / 100$ & $0 / 0$ & $31 / 31$ \\
\hline Apr/1996 & 16 a 18 & $90 / 100$ & $0 / 0$ & $30 / 30$ \\
\hline \multicolumn{5}{|c|}{ Sandbar opening Apr, 26, 1996} \\
\hline May/1996 & $\mathrm{N}$ & -120 & -123 & -124 \\
\hline Jun/1996 & N & $10 / 15$ & $15 / 6$ & $24 / 24$ \\
\hline Jul/1996 & 1 a 2 & $20 / 30$ & $12 / 5$ & $22 / 22$ \\
\hline Aug/1996 & 9 a 12 & $40 / 60$ & $10 / 3$ & $22 / 22$ \\
\hline Sep/1996 & 3 a 5 & $75 / 85$ & $6 / 3$ & $25 / 24$ \\
\hline Oct/1996 & 1 a 3 & $130 / 155$ & $8 / 2$ & $25 / 25$ \\
\hline Nov/1996 & 1 a 3 & $150 / 190$ & $0 / 0$ & $26 / 26$ \\
\hline \multicolumn{5}{|c|}{ Sandbar opening Nov, 16, 1996} \\
\hline Dec/1996 & $N$ & $-1-$ & $-1-$ & $-1-$ \\
\hline \multicolumn{5}{|c|}{ Sandbar opening Jan, 06, 1997} \\
\hline Feb/1997 & $\mathrm{N}$ & -120 & -13 & -125 \\
\hline $\mathrm{Mar} / 1997$ & 2 a 5 & $25 / 85$ & $15 / 14$ & $30 / 27$ \\
\hline Apr/1997 & 3 a 6 & $80 / 100$ & $8 / 9$ & $24 / 28$ \\
\hline May/1997 & 1 a 3 & $90 / 105$ & $5 / 5$ & $27 / 26$ \\
\hline Jun/1997 & 4 a 8 & $80 / 97$ & $10 / 2$ & $20 / 20$ \\
\hline $\mathrm{Jul} / 1997$ & 2 a 5 & $100 / 170$ & $11 / 0$ & $23 / 23$ \\
\hline
\end{tabular}

There was no statistically significant difference (ANCOVA, $p>0.05$ ) between the different intervals of sandbar breachings, for neither the weight/total length curves or the weight/cephalotorax length curves and a significant difference (ANCOVA, p < 0.001) between the curves for males and females. Therefore, the results are presented separately for males and females, encompassing the entire sampling period.

The relationship weight/total length obtained for males $\left(\mathrm{W}_{\mathrm{t}}=0.000003 \mathrm{Lt}_{\mathrm{t}}^{3.27}\right.$, $\left.\mathrm{r}^{2}=0.87\right)$ and females $\left(\mathrm{W}_{\mathrm{t}}=0.000006 \mathrm{~L}_{\mathrm{t}}^{3.13}, \mathrm{r}^{2}=0.89\right)$ of $M$. acanthurus (Fig. $1 \mathrm{~A}$ and B), as well as the distribution of occurrence in size classes, showed that the males reach bigger lengths and weights than the females in reproductive age. The coefficients of determination were high for both estimates, showing that the exponential model of growth in weight describes accurately the weight/length relationship for the adult stage of this species.

The values for the coefficients of growth, 3.13 for females and 3.27 for males, showed that the species exhibits, at Imboassica lagoon, positive allometric growth. The curves of the weight/cephalotorax length relationship also exhibited coefficients of growth higher than 3, corroborating the results found regarding the total length. For females, the obtained curve was $\mathrm{W}_{\mathrm{t}}=0.00002 \mathrm{~L}_{\mathrm{c}}{ }^{3.3054}$, and for males $\mathrm{W}_{\mathrm{t}}=0.00001 \mathrm{~L}_{\mathrm{c}}^{3.4982}$ 

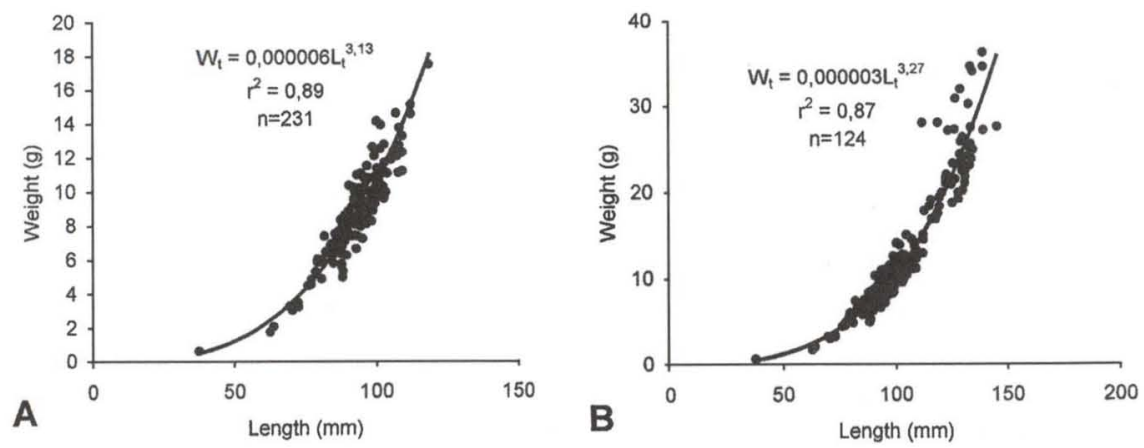

Fig. 1. Weight/length curves of Macrobrachium acanthurus at Imboassica lagoon. (A) Females, (B) males.

The linear relationships between the cephalotorax growth and the total length of males and females determined the following equations: for females, $\mathrm{L}_{\mathrm{c}}$ $=0.5331 \mathrm{~L}_{\mathrm{t}},\left(\mathrm{r}^{2}=0.91\right)$ and for males: $\mathrm{L}_{\mathrm{c}}=0.5043 \mathrm{~L}_{\mathrm{t}}\left(\mathrm{r}^{2}=0.90\right)$. These equations showed that the cephalotorax length, in the adult stage of $M$. acanthurus, represents approximately $50 \%$ of its total length, as the relative growth between $\mathrm{L}_{c}$ and $\mathrm{L}_{\mathrm{t}}$.

The results of the Relative Condition Factor (Tab. II) determined for all study period were significantly different and smaller than the expected pattern (1), both for males $(0.90)$ and females (0.89).

Table II. Student ' $\mathrm{t}$ ' test for comparison in average of $M$. acanthurus relative condition factor $\left(K_{r}\right)$ in the total sampling period, to males and females. $\left(^{*}\right) p<0.05$, (n) number of organisms, (SD) standard deviation.

\begin{tabular}{lcccccc}
\hline Gender & Kr expected & Kr medium observed & $n$ & SD & $T_{\text {calc }}$ & $T_{\text {crit }}(\mathrm{n}-1$ gl $)$ \\
\hline Females & 1 & 0.8889 & 231 & 0.1083 & $17.62^{*}$ & 1.97 \\
Males & 1 & 0.9043 & 124 & 0.1677 & $4.53^{*}$ & 2.00 \\
\hline
\end{tabular}

\section{DISCUSSION}

Macrobrachium acanthurus is found at Imboassica lagoon in two stages of its life cycle: larvae and reproductive adults (ALBERTONI et al. 1999). Since it is a typical species of coastal areas (COELHO \& RAMOS-PORTO 1985), it migrates for its reproduction and for hatching. Its larvae must be exposed to an amount of salinity for their development (DoBKIN 1970; JALIHAL et al. 1993), and so the adult males and females migrate in the reproductive season, going to mesohaline waters. It was observed by ABREU (1980), that this species migrates from the rivers close to the bay of Ubatuba (São Paulo) to the estuarine areas. 
At Imboassica lagoon, there is still a link with the Imboassica river, which probably allows for the migration of the adults of Macrobrachium acanthurus for reproduction and laying of the eggs. This migration probably occurs with the adults in the reproductive stage moving from the river, which ends at the lagoon, or from areas close to the mouth of this river. At this site, the dense stands of aquatic macrophytes may offer abundant shelter and food for juveniles and young adults. According ODINETZ-COLlaRT \& MOREIRA (1993), Macrobrachium amazonicum Heller, 1862 growth in macrophyte stands in Amazonian lakes, suggesting that in these stands the species finds, as well as shelter against predators, diversified and abundant food.

The obtained results show that the adult population at Imboassica lagoon occupies the aquatic macrophyte stands, both emergent (especially Typha domingensis Pers and Eleocharis mutata (L.) Roem. et Schult) and submersed (Chara spp), with, however, different proportions of males and females. In the area closest to the ocean (Station 1), where the submersed aquatic macrophytes are sparse and the emergent occur only at the margins, the females are found in greater numbers, and the opposite is observed in the area further away from the sea, among the submersed and emergent macrophytes (Station 2). This difference suggests that the fecundation must occur in the more sheltered habitats, among the aquatic vegetation, and that the females migrate to the area closest to the sandbar, searching for waters with higher salinity, to spawning.

Some animals, after reaching the reproductive stage, stop their growth. In crustaceans there is a continued growth, although at a slower pace than in the first stages of the life cycle. It is common to observe great differences in the growth rates between the males and females, and between juveniles and adults (HARTNOLL 1978), and adult organisms invest more energy in reproduction than in growth (DAY \& TAYLOR 1997).

According to the results found, it was verified that the weight/total length relationships and weight/cephalotorax length relationships had significant differences between males and females. These differences may by due to the great sexual dimorphism in the adult stage of Macrobrachium acanthurus, with males being usually larger than females, exhibiting a well-developed second pair of pereiopods, in the shape of strong chelae (CAMACHO et al. 1997), or due to the stage of development of the gonads and of the egg mass in females, as detected by LOB $\tilde{O} O$ \& LONA (1979), in Macrobrachium holthuisi Genofre \& Lobão, 1976.

Some species of this genus have no sexual dimorphism in the weight/ length relationship, such as Macrobrachium holthuisi (LOBÃO \& LONA 1979) and M. borelli Nobili, 1836 (BOND \& BUCKUP 1983). This relationship, however, differs among the genera for other species such as $M$. malcomsonii Milne Edwards, 1844 (IBRAHIM 1962 apud VALENTI et al. 1987), and M. carcinus Linnaeus, 1758 (VAlENTI et al. 1987). For M. potiuna Müller, 1880, BOND \& BUCKUP (1983) and SOUZA \& FONTOURA (1995), have found a significant difference in the relations between males and females, and both authors conclude that the species growth is allometrically positive, with females growing proportionately more in weight than males. 
The potential weight/length relationships were developed and used for fish population dynamics (WEATHERLEY 1972; WEATHERLEY \& GILL 1987), and allow for the determination of the growth pattern of a species, whether isometric or allometric (TESH 1968). The values of the growth coefficient obtained for adult males and females of Macrobrachium acanthurus, both higher than 3, shown that the growth pattern of the species is positive allometric. In the determination of the weight/length relationship for $M$. acanthurus, VALENTI et al. (1987) obtained the equation $\mathrm{W}_{\mathrm{t}}=0.00635 \mathrm{Lt}_{\mathrm{t}}^{3.25}$, suggesting that the species has allometric growth.

The biometric relationships have been used by several authors for the determination of the relative growth in crustaceans (HARTNOLL 1978). Usually, in Decapoda, the cephalotorax length is used as a variable dimension, related to the total length, the reference. In our study, the proportions found among the total length and the cephalotorax length, $53 \%$ of the total length of females, and $50 \%$ of the total length of males, showed values close to those found for other species of this genus.

For several species of Macrobrachium, the relationships between the cephalotorax length and total length showed that the cephalotorax, usually, corresponds to approximately $50 \%$ of the length of the organism. To M. amazonicum, $\mathrm{L}_{\mathrm{c}}=0.46$ $\mathrm{L}_{\mathrm{t}}$, for males and females (COELHO et al. 1982), to M. carcinus, LOBÃO et al. (1986b) found $\mathrm{L}_{\mathrm{c}}=0.456 \mathrm{~L}_{\mathrm{t}}$ for males, and $\mathrm{L}_{\mathrm{c}}=0.442 \mathrm{~L}_{\mathrm{t}}$ for females and the cephalotorax length corresponds to $40 \%$ of the total length for $M$. holthuisi, according to LOBÃO \& LONA (1979).

These values of relative growth are important for management systems of this species, especially in the areas of fishery biology and aquaculture, where they may be used as reference for the establishment of appropriate size for fishing effort, related to the proportion of growth of the different parts of the animal, since these proportions may change in the course of its development.

The analysis of the data of weight/length individually and for the species provide information on the general condition of an organism related to the environment, and of its stages of development, through the estimate of the condition factor (LE CREN 1951). Some authors have used this factor in the analysis of fish (VAZZOLER \& VAZZOLER 1965; BRAGA 1986, 1997, among others), and crustacean populations (DU PREEZ \& MCLACHLAN 1984). According to LE CREN (1951), the relative condition factor $\left(\mathrm{K}_{\mathrm{r}}\right)$ is the best estimate, since it evaluates the individual expected weight from the species weight/length relationship.

Through the results obtained for Macrobrachium acanthurus at Imboassica lagoon, the relative condition factor was lower than expected, both for males and females. As the sampled population stratum is reproductive adults, it may be expected that these results are a consequence of the migration of the species from the growing areas to the sites of reproduction.

However, other factors, such as the energetic deficit through the migration for the reproduction, the laying of the eggs, which means a decrease of approximately $15 \%$ (in average) of the total weight of females (ALBERTONI et al. 2002) and the impact of the repeated sandbar breaching to which this lagoon is exposed, may act as adverse factors regarding the condition of these organisms, and therefore decreasing their weight below the expected values for a definite length, as reflected by the average values of $\mathrm{K}_{\mathrm{r}}, 0.89$ for females and 0.90 for males. 
ACKNOWLEDGMENTS. The authors thank CAPES, CNPq and PETROBRAS for financial support of research project.

\section{REFERENCES}

ABREU, J. 1980. Distribuição e ecologia dos Decapoda numa área estuarina de Ubatuba (SP). Bol. Inst. Oceanogr., São Paulo, 29 (2): 1-3.

ALBERTONI, E.F. 1998a. Camarões da lagoa Imboassica: dados preliminares e perspectivas de manejo, p. 359-371. In: F.A. Esteves (Ed.). Ecologia das Lagoas Costeiras do Parque Nacional da Restinga de Jurubatiba e do Município de Macaé (RJ). Rio de Janeiro, NUPEM/UFRJ, 464p.

. 1998b. Ocorrência de camarões Peneídeos e Paleomonídeos nas lagoas Imboassica, Cabiúnas, Comprida e Carapebus, p. 351-358. In: F.A. Esteves (Ed.). Ecologia das Lagoas Costeiras do Parque Nacional da Restinga de Jurubatiba e do Município de Macaé (RJ). Rio de Janeiro, NUPEM/UFRJ, 464p.

Albertoni, E.F.; C. Palma-Silva \& F.A. Esteves. 1999. Larvae and post-larvae of Penaeidae and Palaemonidae in costal lagoons of the north of Rio de Janeiro (Macaé, RJ). Rev. Brasil. Biol. 59 (1): 109-117.

Albertoni, E.F.; C. Palma-Silva \& F. A. Esteves. 2001. Macroinvertebrates associated with Chara in a tropical coastal lagoon (Brazil). Hydrobiologia, Dordrecht, 457 (1/3): 215-224

Albertoni, E.F.; C. Palma-Silva \& F. A. Esteves. 2002. Fecundity of Macrobrachium acanthurus Wiegmann, 1836 (Decapoda: Palaemonidae) in a tropical coastal lagoon subjected to human impacts (Macaé, Brazil). Acta Limnol. Bras., São Paulo, 14 (1): 71-80.

AMADOR, E.S. 1985. Lagunas Fluminenses: classificação com base na origem, idade e processos da evolução. An. Acad. Bras. Ciênc. 57: 526-527.

BATSCHELET, E. 1978. Introdução à Matemática para Biocientistas. São Paulo, Interciência/EDUSP, $596 \mathrm{p}$.

Bond, G. \& L. Buckup. 1982. O ciclo reprodutor de Macrobrachium borellii (Nobili, 1896) e Macrobrachium potiuna (Müller, 1880) (Crustacea, Decapoda, Palaemonidae) e suas relações com a temperatura. Rev. Brasil. Biol. 42 (3): 473-483.

Bond, G. \& L. BucKuP. 1983. O cultivo de Macrobrachium borellii (Nobili, 1896) e de Macrobrachium potiuna (Müller, 1880) em laboratório (Crustacea, Decapoda, Palaemonidae). Rev. Brasil. Biol. 43 (2): 177-190.

Bond-Buckup, G. \& L. Buckup. 1989. Os Palaemonidae de águas continentais do Brasil meridional (Crustacea, Decapoda). Rev. Bras. Biol. 49 (4): 883-896.

BRAGA, F.M.S. 1986. Estudo entre fator de condição e relação peso/comprimento para alguns peixes marinhos. Rev. Brasil. Biol. 46 (2): 339-346.

— 1997. Análise da equação alométrica na relação peso e comprimento e o fator de condição em Plagioscion squamosissimus (Teleostei, Sciaenidae). Rev. Brasil. Biol. 57 (3): 417-425.

BRANCO, C.W.C. 1998. Composição e aspectos ecológicos das comunidades zooplanctônicas nas lagoas Imboassica, Cabiúnas e Comprida, p. 247-271. In: F.A.Esteves (Ed.). Ecologia das Lagoas Costeiras do Parque Nacional da Restinga de Jurubatiba e do Município de Macaé (RJ). Rio de Janeiro, NUPEM/UFRJ, 464p.

Camacho, M.E.; F. Álvarez \& J.L. Villalobos. 1997. Palaemonidae (camarones de río, langostinos), p. 411-414. In: E.G. Soriano; R. Dirzo \& R.C. Vogt (Eds). Historia Natural de Los Tuxtlas. México, UNAM, CONABIO, 647p.

Coelho, P.A \& M. Ramos-Porto. 1985. Camarões de água doce do Brasil: Distribuição geográfica. Revta bras. Zool. 2 (6): 405-410.

Coelho,P.A.; M. Ramos-Porto; A.V. Barreto \& V.E. Costa. 1982. Crescimento em viveiro de cultivo do camarão canela (Macrobrachium amazonicum) (Decapoda, Palaemonidae). Revta bras. Zool. $1(1): 45-49$.

DAY, T. \& P.D. TAYLOR. 1997. Von Bertalanffy's growth equation should not be used to model age and

Revta bras. Zool. 19 (Supl. 2): 61 - 70, 2002 
size at maturity. Amer. Nat. 149 (2): 381-393.

Doвkin, S. 1970. Manual de metodos para el estudio de larvas y primeras postlarvas de camarones y gambas. Inst. Nat. Invest. Pesq. Mexico, Serie Divulgación, 4: 1-82p.

DU PREEZ, H.H. \& A. MCLACHLAN. 1984. Biology of the three-spot swimming crab Ovalipes punctatus (de Haan). I. Morphometrics and relative growth (Decapoda, Portunidae). Crustaceana 47: 72-82.

Faria, B.M.; M.S. Suzuki; M.M. Petrucio \& A.E. Prast. 1998. Changes in the metabolism of a Brazilian lagoon related to man-made marine entrances. Verh. Internat. Verein. Limnol. 26: $1442-1444$.

HaRTNOLL, R.G. 1978. The determination of relative growth in Crustacea. Crustaceana 34 (3): 281-293.

Holthuis, L.B. 1980. Shrimps and prawns of the world. An annotated catalogue of species of interest to fisheries. FAO Fish Synop. 125: 1-261.

JALIHAL, D.R.; K.N. SANKolli \& S. ShENOY. 1993. Evolution of larval developmental patterns and the process of freshwaterization in the prawn genus Macrobrachium Bate, 1868 (Decapoda, Palaemonidae). Crustaceana 65 (3): 365-376.

LE CREN, E.D. 1951. The length-weight relationship and seasonal cycle in gonad weight and condition in the perch (Perca fluviatilis). Jour. Anim. Ecol. 20: 201-219.

LoBÃo, V.L. \& F.B. LONA. 1979. Biometria e isometria em Macrobrachium holthuisi (Genofre \& Lobão, 1976) (Crustacea-Decapoda). Bol. Inst. Pesca, São Paulo, 6: 17-50.

LoBĀo,V.L.; N.E.T Rojas \& W.C. VALEnTI. 1986a. Fecundidade e fertilidade de Macrobrachium amazonicum (Heller, 1862) (Crustacea, Decapoda) em laboratório. Bol. Inst. Pesca, São Paulo, 13 (2): $15-20$.

LoBÃo,V.L.; W.C. VALENTI \& J.T.C. Mello. 1986b. Crescimento relativo de Macrobrachium carcinus (L.) (Decapoda, Palaemonidae). Bol. Inst. Pesca, São Paulo, 13 (1): 105-109.

Moreira, L.C. \& O. Odinetz-Collart. 1993. Migração vertical nictemeral das larvas de Macrobrachium amazonicum num lago de várzea na Amazônia central, ilha do Careiro, Brasil. Amazoniana, Manaus, 12 (3/4): 385-398.

MüLLER, Y.M.R. \& A.C. PRAZERES. 1992. Influência da salinidade e temperatura da água sobre a captura de Macrobrachium olfersii (Wiegmann, 1836) coletados no canal da lagoa do Peri-Florianópolis,SC. Acta Limnol. Brasil., São Paulo, 4: 175-183.

Odinetz-Collart, O. \& L.C. Moreira. 1993. Potencial pesqueiro de Macrobrachium amazonicum na Amazônia Central (Ilha do Careiro): variação da abundância e do comprimento. Amazoniana, Manaus, 12 (3/4): 399-413.

Oliveira, L.P.H. DE. 1948. Estudo Hidrobiológico das Lagoas de Piratininga e Itaipú. Mem. Inst. Oswaldo Cruz 46 (4):673-718.

Oliveira, L.P.H. DE \& L. KRAU, 1955. Observações Biogeográficas Durante a Abertura da Barra da Lagoa de Saquarema. Mem. Inst. Oswaldo Cruz 53 (2-4): 435-449.

Panosso, R.F.; J.L. Attayde \& D. Muehe. 1998. Morfometria das lagoas Imboassica, Cabiúnas, Comprida e Carapebus: implicações para seu funcionamento e manejo, p. 91-108. In: F.A. ESTEVES (Ed.). Ecologia das lagoas costeiras do parque Nacional da Restinga de Jurubatiba e do Município de Macaé (RJ). Rio de Janeiro, NUPEM/UFRJ, 464p.

Petrucio, M.M. 1998. Caracterização das Lagoas Imboassica, Cabiúnas, Comprida e Carapebus a partir da Temperatura, Salinidade, Condutividade, Alcalinidade, $\mathrm{O}_{2}$ Dissolvido, $\mathrm{pH}$, Transparência e Material em Suspensão, p. 109-121. In: F.A. Esteves (Ed.). Ecologia das Lagoas Costeiras do Parque Nacional da Restinga de Jurubatiba e do Município de Macaé (RJ). Rio de Janeiro, NUPEM/UFRJ, 464p.

SOKAL, R.R. \& F.J. RoHLF. 1979. Biometria - Principios y métodos estadísticos en la investigación biológica. Madrid, H. Blume Ediciones, 832p.

SouzA, G.D. \& N.F. FonToura. 1995. Crescimento de Macrobrachium potiuna no arroio Sapucaia, Município de Gravataí, Rio Grande do Sul (Crustacea, Decapoda, Palaemonidae). Rev. Brasil. Biol. 55 (Supl. 1): 51-63.

TESH, F.W. 1968. Age and Growth, p. 93-123. In: W.E. RICKER (Ed.). Methods for Assessment of Fish

Revta bras. Zool. 19 (Supl. 2): 61 - 70, 2002 
Production in Fresh Waters. Oxford, Blackwell Scientific Publications.

VALENTI, W.C. 1985. Cultivo de Camarões de água doce. São Paulo, Nobel, 82p.

Valenti, W.C.; J.T.C. Mello \& V.L. LobÃo. 1987. Crescimento de Macrobrachium acanthurus

(Wiegmann, 1836) do rio Ribeira do Iguape (Crustacea, Decapoda, Palaemonidae). Rev. Brasil.

Biol. 47 (3): 349-355.

VALENTI, W.C.; V.L.LoBÃo \& J.T.C. MeLLo. 1989. Crescimento relativo de Macrobrachium acanthurus

(Wiegmann, 1836) (Crustacea, Decapoda, Palaemonidae). Revta bras. Zool. 6 (1): 1-8.

VAZZOLER, A.E.A. \& G. VAZzOLER. 1965. Relation between condiction factor and sexual development

in Sardinella aurita (Cuv. \& Val., 1847). An. Acad. Bras. Ciênc. 37 (Supl.): 353-359.

Weatherley, A.H. 1972. Growth and Ecology of Fish Populations. London, Academic Press, 293p. Weatherley, A.H. \& H.S. Gill. 1987. The Biology of Fish Growth. London, Academic Press, 443p.

Received in 13.III.2002; accepted in 06.XI.2002. 